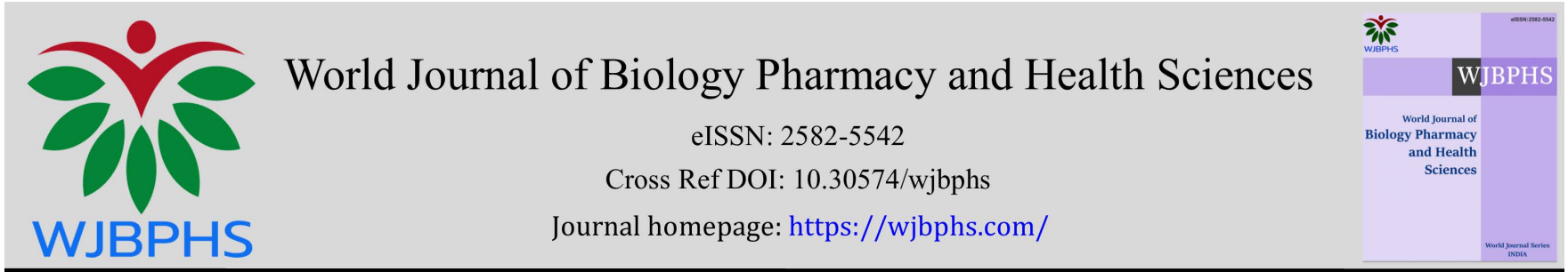

(RESEARCH ARTiCLE)

\title{
Prevalence of scabies among secondary school students in Anambra State, Nigeria
}

\author{
Nweze Kenneth Emeka* \\ Department of Biological Sciences, Chukwuemeka Odumegwu Ojukwu University, Anambra, Nigeria.
}

World Journal of Biology Pharmacy and Health Sciences, 2021, 08(01), 001-007

Publication history: Received on 02 August 2021; revised on 29 September 2021; accepted on 01 October 2021

Article DOI: https://doi.org/10.30574/wjbphs.2021.8.1.0091

\begin{abstract}
Scabies has been listed as one of the Neglected Tropical Diseases. Therefore, this study aimed at estimating the prevalence of Scabies among Secondary School Students in Anambra State, Nigeria. A survey of Scabies infection was conducted in fifty (50) randomly selected secondary schools in the three geographical zones of Anambra State, Nigeria. A well-structured questionnaire was employed to elucidate information on age, sex and also on knowledge, attitude and perception (KAP). Focus group discussions, direct clinical observations and microscopic examinations using the skin scraping test method for the confirmation of scabies infestation were also employed. Data analysis was done using a statistical package for social sciences (SPSS) version 23 and Microsoft Excel version 16. Out of the five thousand (5000) students examined $500(10.0 \%)$ were identified as positive from the research works, the sex-specific prevalent rate showed that 209 out of the 3000 females (6.97\%) were positive while 291 out of the 2000 males (14.55\%) were positive. The age-specific prevalence showed that age groups 10 to 12 years had the highest prevalence rate $(29.0 \%)$ and $9.6 \%$ in both the male and female students respectively. The infectivity rate among urban and rural schools showed that rural students were more prone to scabies infections (14.12\%) than their urban counterparts (5.88\%) and the difference was statistically significant. The result of this study helped identify some students with Scabies infection in Anambra state Nigeria for appropriate treatment, prevention and control measures to curb the menace of Scabies infestation.
\end{abstract}

Keywords: Scabies; Epidemic; Neglected Tropical Disease; Early diagnosis; Treatment.

\section{Introduction}

Scabies is a common, contagious skin infestation occurring globally but more prevalent in developing countries [1]. It is an often neglected parasitic disease caused by infestation with the ectoparasitic mite, Sarcoptes scabei var. hominis which is commonly known as itch mite. It burrows into the epidermis where it lays eggs and has the potentials of causing major public health problems, especially in resource-poor countries [1].

Scabies affects more than 130 million people globally at any time and in 2010, it was estimated that the direct effects of infestation on the skin alone led to more than 1.5 million people living with disabilities (Amro et al., 2012). Despite the availability of effective chemotherapy, the prevalence of the disease ranges from $0.2 \%$ to as high as $71.4 \%$ [1]. Outbreaks in the developed world amongst vulnerable communities and health institutions contribute a significant cost to the health services managing them while in developing countries; it contributes to disease burden from secondary infections and occurrence of complications such as acute post-streptococcal glomerulonephritis, septicemia and rheumatic heart disease [1].

Scabies has been a scourge among human beings for thousands of years. Its worldwide occurrence with epidemics during the war, famine and overcrowding is responsible for an estimated 300 million people currently infested (Arlian

\footnotetext{
* Corresponding author: Nweze Kenneth Emeka

Department of Biological Sciences, Chukwuemeka Odumegwu Ojukwu University, Anambra, Nigeria. 
et al., 2004). Recent immunological findings such as cross-reactivity with house dust mite allergens and an altered Thelper-1/T-helper-2 pattern contribute to a better understanding of the pathomechanism [2].

Sarcoptes scabiei or the itch mite is a parasitic mite (an arthropod) that burrows into the skin and causes scabies. The mite is found in all parts of the world [1]. Humans are not the only mammals that can become infected. Other mammals, such as wild and domesticated dogs and cats (in which it is one cause of mange) as well as ungulates, wild boars, bovids, wombats, koalas, and great apes are affected [1]. Sarcoptes is a genus of skin parasites, and part of the larger family of mites collectively known as "scab mites". They are also related to the scab mite Psoroptes, also a mite that infests the skin of domestic animals. Sarcoptic mange affects domestic animals and similar infestations in domestic fowls cause the disease known as "scaly leg". The effects of S. scabiei are the most well-known, causing "scabies", or "the itch". The adult female mite, having been fertilized, burrows into the skin (usually at the hands or wrists, but other parts of the body may also be affected), and lays its eggs [3].

The mode of transmission is by close physical skin-to-skin contact from an infected person, although contact with contaminated fomites such as clothing and bed linen may occur. Classically, scabies presents with burrows, erythematous papules and generalized pruritus that is typically worse at night. Its burrows are usually located between the fingers, in the flexure of the wrist, elbows or axillae, or on the genitals or breasts [1]. The burrows may sometimes be difficult to identify and in infants and the elderly, they may be found on the head and neck and may present as vesicles, pustules or nodules. Scabies may be misdiagnosed as eczema, impetigo, tinea corporis (ringworm) and psoriasis, and can lead to stigmatization, depression, insomnia and significant financial costs [4]. Other factors that may affect transmission include bed sharing and large families with many children. Lack of expertise in diagnosis may lead to failure to recognize scabies, delays in treatment of cases and their contacts and further spread of infection while lack of clean running water may contribute to secondary skin infections and related complications. Diagnosis of scabies is usually based on a history of pruritic rash, typically worse at night and presenting in characteristic locations. Definitive diagnosis may be made through skin scraping and microscopical examination of a burrow, burrow ink test or dermoscopy [5] and [6] Treatment of cases and household contacts should be carried out to avoid reinfestation and transmission.

Since Scabies has been listed as one of the Neglected Tropical Diseases (NTD), there is an urgent need to estimate the prevalence of this infection in Anambra State, which is one of the leading states academically with numerous secondary schools both in rural and urban centres, hence a fertile ground for this study. Therefore, this study aimed at estimating the prevalence of Scabies among Secondary School Students in Anambra State, Nigeria.

\section{Material and methods}

\subsection{Study area}

The study area was made up of Secondary Schools Students in Anambra State, Nigeria. Anambra State is located in the South-Eastern part of Nigeria, having boundaries with Delta State to the west, Imo State and River State to the South, Enugu State to the East, and Kogi State to the North. The indigenous ethnic groups in Anambra State are the Igbos, (98\% of the population) and a small population of Igala ( $2 \%$ of the population) who live mainly in the North-Western part of the State.

The number of secondary schools in Anambra State Nigeria as of $7^{\text {th }}$ May 2019 is more than three hundred (300) public, private or mission schools.

Anambra Central has the following local government Areas: Awka North, Awka South, Njikoka, Anaocha, Dunukofia, Idemili North and Idemili South.

Anambra North Senatorial District comprises Anambra East, Anambra West, Ayamelum, Oyi, Onitsha North, Onitsha South, and Ogbaru.

Anambra South Senatorial District has the following Local Government Areas: Aguata, Ihiala, Nnewi South, Nnewi North, Ekwusigo, Orumba North and Orumba South. 


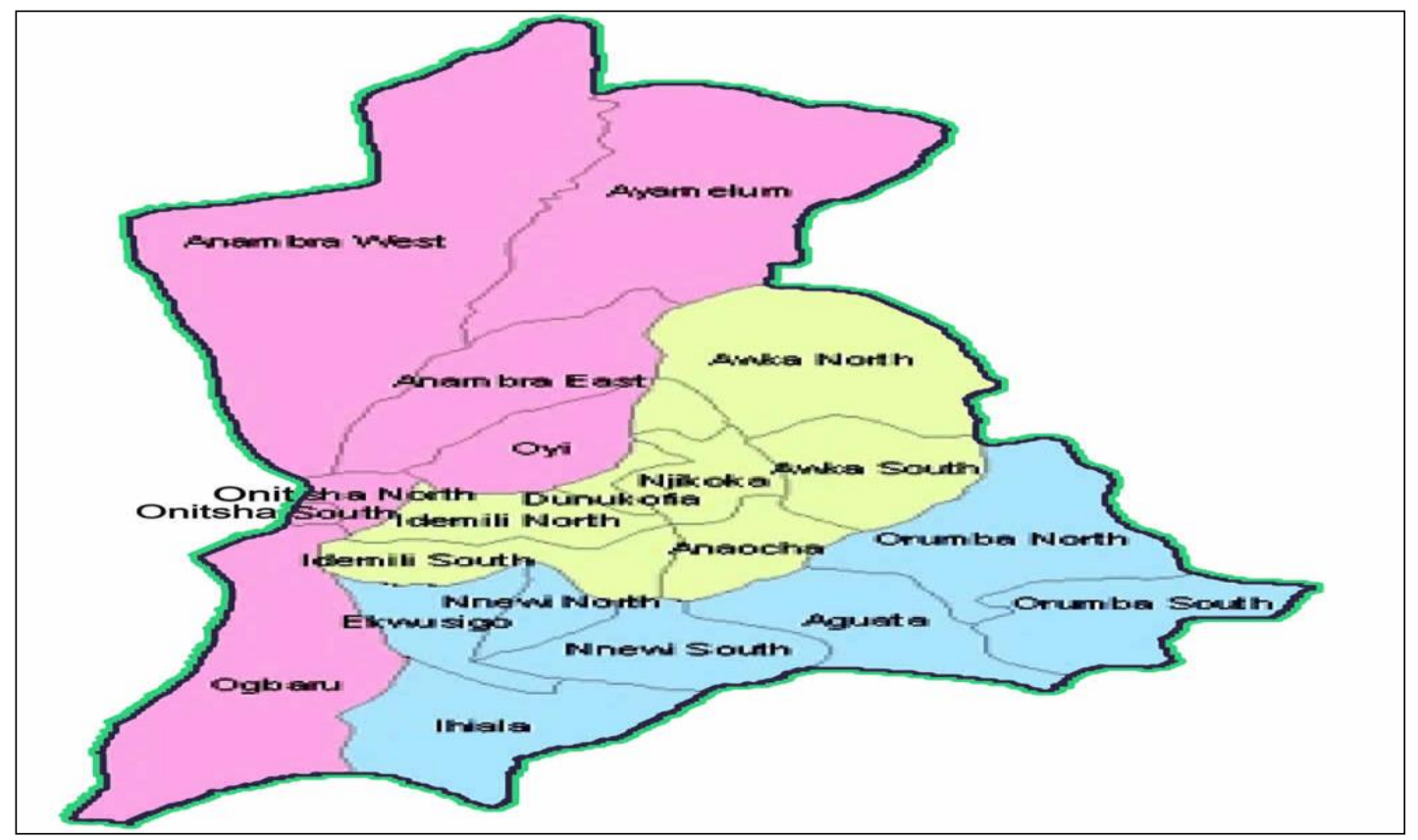

Figure 1 Map of Anambra State, Nigeria

\subsection{Source: Statistics of Anambra State Election 2013.}

The random selection of Secondary Schools for this research work cut across fifty (50) Secondary Schools in all the three senatorial zones in the state. These Secondary Schools were randomly selected cutting across the Rural and Urban Schools in the State.

\subsection{Study design}

In the design of this study, structural questionnaires, focus group discussions, interviews and direct clinical observations by a Dermatologist was employed to obtain data and the laboratory diagnosis for confirmation of the infection was done using the skin scraping test method. The survey was carried out between July 2019 to July 2020. Within the realm of this study, Scabies was defined based on a symptomatic description with typical skin lesions such as papules, vesicular rash and nodules and with pruritus that intensified at night. The students were carefully examined clinically for scabies infestation by the clinical research team including a Dermatologist. This is of paramount importance to differentiate scabies from other skin infections like eczema, impetigo, Tinea corpovis (Ringworm) and psoriasis.

\subsection{Statistical analysis}

Generated data were analyzed using a statistical package for social sciences (SPSS) for windows version 20.0 (SPSS. Inc., Chicago 11., USA) and students age and gender was tabulated and the percentage calculated.

\section{Results}

A total number of five thousand (5000) students were examined for scabies infestation amongst the randomly selected secondary schools in the three Senatorial zones of Anambra State Nigeria. Out of which, 2000 male students were examined and 291 positive cases were identified and 3000 female students were examined and 209 positive cases were identified. This gives an incidences rate of 500 cases $(10.00 \%)$.

Table 1 below shows the gender distribution of scabies infection among 5000 students examined. The table showed that male students were more prone to scabies infestation with a prevalence/infectivity rate of $14.55 \%$ while the female students had a prevalence rate of $6.97 \%$.

Table 2 shows the age distribution of scabies infection among 2000 male students examined. The table showed that the age brackets of 10 to 12 years had more prevalence rates of $29.60 \%$ followed by the age brackets 13 to 16 years with 
$15.40 \%$. The age brackets 16 to years had $9.60 \%$ while the least prevalence rates were the age brackets 19 to 20 with $3.60 \%$.

Table 1 Gender Distribution of Scabies Infection among 5000 Students examined

\begin{tabular}{|l|l|l|l|}
\hline $\begin{array}{l}\text { Gender } \\
\text { (SEX) }\end{array}$ & $\begin{array}{l}\text { Total No. of students } \\
\text { examined. }\end{array}$ & $\begin{array}{l}\text { Total No. of students ' } \\
\text { infected. }\end{array}$ & $\begin{array}{l}\text { Prevalence / Infectivity } \\
\text { Rate (\%) }\end{array}$ \\
\hline Male & 2000 & 291 & $14.55 \%$ \\
\hline Female & 3000 & 209 & $6.97 \%$ \\
\hline Total & 5000 & 500 & $10.0 \%$ \\
\hline
\end{tabular}

Table 2 Age Distribution of Scabies Infection among 2000 male students examined

\begin{tabular}{|l|l|l|l|}
\hline $\begin{array}{l}\text { Age } \\
\text { (Years) }\end{array}$ & $\begin{array}{l}\text { Total No. of students } \\
\text { examined. }\end{array}$ & $\begin{array}{l}\text { Total No. of students } \\
\text { infected. }\end{array}$ & $\begin{array}{l}\text { Prevalence/Infectivity rate } \\
\text { (\%) }\end{array}$ \\
\hline $10-12$ & 500 & 148 & 29.60 \\
\hline $13-15$ & 500 & 77 & 15.40 \\
\hline $16-18$ & 500 & 48 & 9.60 \\
\hline $19-20$ & 500 & 18 & 3.60 \\
\hline Total & 2000 & 291 & 14.55 \\
\hline
\end{tabular}

Table 3 shows the age distribution of scabies infection among the female students examined. The table showed that the female students with age bracket 10 to 12 years had the highest prevalence rate of $9.60 \%$ followed by age brackets 16 to 18 years with $8.27 \%$. The age brackets 13 to 15 had $7.04 \%$ while the age brackets 19 to 20 years had the least prevalence rate $2.93 \%$.

Table 3 Age Distribution of Scabies Infection among the female students examined

\begin{tabular}{|l|l|l|l|}
\hline $\begin{array}{l}\text { Age } \\
\text { (Years) }\end{array}$ & Total No. of students examined. & Total No. of students infected. & $\begin{array}{l}\text { Prevalence/Infectivity rate } \\
(\%)\end{array}$ \\
\hline $10-12$ & 750 & 72 & 9.60 \\
\hline $13-15$ & 750 & 53 & 7.07 \\
\hline $16-18$ & 750 & 62 & 8.27 \\
\hline $19-20$ & 750 & 22 & 2.93 \\
\hline Total & 3000 & 209 & 6.97 \\
\hline
\end{tabular}

Table 4 Infectivity rate of Scabies between Rural And Urban Schools

\begin{tabular}{|l|l|l|l|}
\hline Locality & Total examined & Total positive & \% \\
\hline Rural & 2,500 & 353 & 14.12 \\
\hline Urban & 2,500 & 147 & 5.88 \\
\hline Total & 5000 & 5000 & 20.00 \\
\hline
\end{tabular}


Table 4 shows the Infectivity rate of Scabies between Rural and Urban Schools. Students in rural areas had the highest infectivity rate of $14.12 \%$ than the Urban Students with $5.88 \%$.

Table 5 shows the gender distribution of scabies infection among students examined based on the Rural geographical locations of the students within the three Senatorial zones of the State. The table showed that male students in the rural schools had a higher prevalence rate of $20.10 \%$ while female students had a $10.13 \%$ prevalence rate.

Table 5 Gender distribution of scabies infection among students examined based on the Rural geographical locations of the students within the three Senatorial zones of the State.

\begin{tabular}{|l|l|l|l|}
\hline Gender/Sex & $\begin{array}{l}\text { Total No. of students } \\
\text { examined. }\end{array}$ & $\begin{array}{l}\text { Total No. of students positive on } \\
\text { locations }\end{array}$ & $\begin{array}{l}\text { Prevalence / Infectivity } \\
\text { rate (\%) }\end{array}$ \\
\hline Males & 1000 & 201 & 20.10 \\
\hline Females & 1500 & 152 & 10.13 \\
\hline Total & 2500 & 353 & 14.12 \\
\hline
\end{tabular}

Table 6 shows the gender distribution of scabies infection among students examined based on the Urban geographical locations of the students within the three Senatorial zones of the State. The table showed that the male students in the urban school had a prevalence rate of $9.00 \%$ while the female students had a prevalence rate of $3.80 \%$.

Table 6 Gender distribution of scabies infection among students examined based on the Urban geographical locations of the students within the three Senatorial zones of the State.

\begin{tabular}{|l|l|l|l|}
\hline Gender/Sex & $\begin{array}{l}\text { Total No. of students } \\
\text { examined. }\end{array}$ & $\begin{array}{l}\text { Total No. of students } \\
\text { positive on locations }\end{array}$ & $\begin{array}{l}\text { Prevalence/Infectivity rate } \\
\text { (\%) }\end{array}$ \\
\hline Males & 1000 & 90 & 9.00 \\
\hline Females & 1500 & 57 & 3.80 \\
\hline Total & 2500 & 147 & 5.88 \\
\hline
\end{tabular}

\section{Discussion}

Scabies is increasingly recognized as a common parasitic skin disease in Nigerian children [7], [8] and [9] particularly in poor rural communities where important infrastructural facilities including health care services are unavailable or inadequate. With the current socio-economic and lifestyle patterns of people where living conditions are precarious, for example, students sharing clothing and hostel poor bed spacing, Scabies will continuously be endemic with high prevalence rates in these areas.

The study aimed to assess the incidents and prevalence of Scabies on randomly selected Secondary Schools Students in Anambra State Nigeria from July 2019 to July 2020. A total number of Five thousand (5000) students were examined for scabies infestation amongst the selected secondary schools in the three Senatorial zones of Anambra State Nigeria. These results gave an incidents rate of 500 cases (10.0\%). Out of which, two thousand (2000) male students were examined and two hundred and ninety-one 291 (14.55\%) positive cases were identified and three thousand female students were examined and 209 (6.97\%) positive cases were identified. The results showed that male students were more prone to scabies infestation than female students. These findings tally with the research findings of [10] and [11].

It was also discovered that the age brackets of 10 to 12 years had more prevalence rates in both the male and female students. The study is in agreement with the works of Odueko et al. [11] which reported that school children less than 12 years are more prone to scabies on their studies on epidemiological researches on skin diseases across different centres.

Male students in rural and urban schools had a higher prevalence rate than female students across rural and urban schools. This was as a result that male students expose greater parts of their body and maintain prolong close physical 
contacts which facilitates transmission of scabies mites. This study is in line with the results of [8], [9], [11], [12], [13], [14] and [15].

\section{Conclusion}

group brackets 10 to 12 years had the highest prevalence rate in both the male and female students examined. The students in the rural schools had the highest prevalence rates both in the male and females that participated in the research.

Finally, from this research work, it has become obvious that there were increasing incidents of scabies in secondary school students in Anambra State Nigeria.

Public health enlightenment campaigns and school/community education programs may help in controlling these emerging epidemics in Anambra State and Nigeria in general.

\section{Compliance with ethical standards}

\section{Acknowledgements}

The authors will like to appreciate the research supervisor, research team and the entire staff of the schools used in the study.

\section{Disclosure of conflict of interest}

The author disclose that there was no conflict of interest as regards the research and publication of this manuscript.

\section{Statement of informed consent}

Before this project started, a letter of introduction was submitted to the Anambra State Ministry of Education via the Department of Research Studies (Ethical Unit) Awka. The Ministry then gave another Letter of Introduction to the Principals or Authorities of the randomly selected Secondary Schools in the State to enable the research works accordingly. Oral consent also was obtained from the students before they were recruited for the study. The participants were assured that the information collected will be treated with the utmost confidentiality and for the research work only.

\section{References}

[1] Altraide, DD, Akpa, MR, and George, O. The pattern of skin disorders in a Nigerian tertiary hospital. Journal Public Health Epidemiol 2011; 3:77-181

[2] Arlian, L G, M S Morgan., and J S Ncal. Modulation of cytokine expression in human keratinocyies and fibroblasts by extracts of scabies mites. Am. Journal Trop. Med. Hyg. 2003; 69:652- 656.

[3] Worth C, Heukelbach J, Fengler G, Walter B, Liesenfeld O, Feldmeier H. Impaired quality of life in adults and children with scabies from an impoverished community in Brazil. Int Journal Derrnato 2015; 51:275-82.

[4] Arlian, L G, M S Morgan, and C C Paul. Evidence that scabies mites (Acari: Sarcoptidae) influence production of inierleukin-10 and the function of T-regulatory cells (Trl) in humans. Journal Med. Entomol. 2006; 43:283-287.

[5] Arlian, L G, R A Runyan, and S A Estes. Cross infestivity of Sarcoptes scabiei. Journal Am. Acad. Dermatol. 1984; 10:979-986.

[6] Walton, S F, M R Myerscough, and B J Currie. Studies in vttro on the relative efficacy of current acarieides for Sarcoptes scabiei var. hominis. Trans. R. Soc. Trop. Med. Hyg. 2000; 94:92-96.

[7] Yahaya, H. Change in pattern of skin disease in Kaduna, North Central Nigeria. Int. Journal Dermatol. 2007; 46: 936-943.

[8] Nnoruka EN. Skin disese in South East Nigeria: A current perspective. Int. Journal Dermatol. 2005; 44:29-33.

[9] Onayemi O, Isezuo SA, Njoku CH Prevalence of different skin conditions in an out patience setting in North Western Nigeria. Int. Journal Dermatol. 2005; 44:7-11. 
[10] Hengge UR, Currie BJ, Jager G, Lupi O, Schwartz RA. Scabies: A ubiquitous neglected skin disease. Lancet Infect Dis 2006; 6:769-79

[11] Odueko, O M, O Onayemi, and G A Oyedeji. A prevalence survey of skin diseases in Nigerian children. Niger. Journal Med. 2001; 10:64-67.

[12] World Health Organization. Epidemiology and Management of common skin diseases in children in developing countries. WHO, Geneva. 2005; Pp. 150-160.

[13] Steer AC, Jenny AW, Kado J. High burden of impetigo and scabis in a tropical country PC05: Neglected Tropical Disease 2009; 3:467.

[14] Amro, A., Hamarsheh, O, Epidemiology of scabies in the West Bank, Palestinian Territories (Occupied). Int Journal Infect Dis. 2012; 16: 202-236.

[15] Feldmeier H, Jackson A, Ariza L. The epidemiology of scabies in an impoverished community in rural Brazil: presence and severity of disease associated with poor living conditions and illiteracy. AM. Acad-Dermatol. 2009; 601:436-443. 